\title{
PENGARUH PENDIDIKAN AGAMA KRISTEN DALAM PENINGKATKAN PEMAHAMAN MAHASISWA KRISTEN TENTANG KRISTOLOGI ALKITABIAH
}

\author{
${ }^{* 1}$ Yuliati, ${ }^{* 2}$ Stanley Santoso \\ ${ }^{12}$ Dosen Sekolah Tinggi Teologi Gamaliel, Surakarta \\ Email: ${ }^{1}$ tyuliati@ stt-gamaliel.ac.id, ${ }^{2}$ stanley@stt-gamaliel.ac.id
}

\begin{abstract}
ABSTRAK-Mahasiswa Kristen sering memprioritaskan mata kuliah lain yang sesuai dengan program studinya dibandingkan dengan Pendidikan Agama Kristen (PAK) yang merupakan mata kuliah umum. Kebijakan Kampus Merdeka berpotensi membuat mahasiswa Kristen tidak lagi memilih mata kuliah PAK. Penelitian ini bertujuan untuk mengetahui pengaruh PAK terhadap pemahaman mahasiswa Kristen semester satu Fakultas Ilmu Sosial dan Ilmu Politik Universitas Sebelas Maret Surakarta tentang Kristologi alkitabiah. Penelitian ini menggunakan pendekatan kuantitatif dengan metode one group pretest postest. Populasi yaitu mahasiswa Kristen angkatan 2019 yang mengambil Mata Kuliah PAK di Fakultas Ilmu Sosial dan Ilmu Politik Universitas Sebelas Maret Surakarta (UNS) sebanyak 30 mahasiswa. Kesimpulan dari penelitian ini adalah pertama, PAK berpengaruh meningkatkan pemahaman mahasiswa tentang Kristologi Alkitabiah sebesar 47,9\%. Kedua, Pembelajaran PAK memerlukan metode pengajaran yang beragam dan intensitas pengulangan materi yang tinggi.
\end{abstract}

Kata Kunci: Kristologi alkitabiah, PAK, Pengaruh

\begin{abstract}
Christian Student often prioritize their main subject more than general subject such as Christian Religious Education. Kampus Merdeka policy potentially make Christian student will not choose Christian Religious Education any more. This research aims to understand the influence of Christian Religious Education to Christian Bachelor program students, of 2019 at Faculty of Social and political science of Sebelas Maret University (UNS), understanding on biblical christology. The research uses quantitative approach with one group pretest postest method on 30 Christian Bachelor's program students, of 2019 at Faculty of Social and political science of Sebelas Maret University (UNS). Based on research results and discussions, it can be concluded that Christian Religious Education increases understanding of students on biblical christology by 47,9\%. Effective Christian Religious Education needs repetitive delivery of material with varied methods.
\end{abstract}

Keyword: Biblical Christology, Christian Religious Education, influence

\section{PENDAHULUAN}

Globalisasi menantang setiap orang salah satunya adalah untuk menjadi seorang warga Negara yang berkarakter baik. $^{1}$ Mahasiswa sebagai calon sarjana

\footnotetext{
${ }^{1}$ Dasim Budimansyah. Tantangan Globalisasi Terhadap Pembinaan Wawasan Kebangsaan Dan Cinta Tanah Air Di Sekolah.
}

Kristen dituntut untuk siap dalam menghadapi tantangan globalisasi ini. Mahasiswa Kristen sudah seharusnya memiliki karakter Kristus yang lebih unggul dari sekadar karakter baik saja. Karena itu, ia perlu mengenal Kristus yang

Jurnal Penelitian Pendidikan Vol. 11, No. 1, April 2010. 
sebenarnya dan karakter-Nya yang sempurna terlebih dulu.

Kristen bukan hanya sekadar agama. Nama Kristen sangat erat dengan pengharapan mesias yang digenapi dalam Yesus Kristus. $^{2}$ Keselamatan dalam agama Kristen bergantung pada siapa Yesus yang melakukan karya keselamatan manusia. ${ }^{3}$ Karena itu, pemahaman tentang Kristologi merupakan isu sentral dalam Pendidikan Agama Kristen (PAK). Mahasiswa Kristen sebagai pengikut Yesus perlu memahami siapa Kristus yang sebenarnya untuk bisa menghidupi imannya.

Pendidikan Agama Kristen merupakan salah satu mata kuliah yang diikuti mahasiswa Kristen di perguruan tinggi. Materi ajar PAK berisi pengenalan akan Tuhan Yang Maha Esa dan Yesus Kristus adalah Tuhan. Namun, materi ajar PAK kurang diminati oleh mahasiswa Kristen di perguruan tinggi, menurut pengamatan peneliti sebagai dosen PAK. Mahasiswa Kristen sering memprioritaskan mata kuliah lain yang sesuai dengan program studinya dibandingkan dengan PAK yang merupakan mata kuliah umum. Mahasiswa ingin memaksimalkan kompetensinya demi menjawab tatangan globalisasi sehingga mengabaikan mata kuliah yang menurutnya kurang penting. Alasan lainnya, PAK telah diterima seorang mahasiswa sejak jenjang Sekolah Dasar (SD) sehingga ia mengalami kejenuhan pada materi yang dianggap sama. Mahasiswa sering menganggap dirinya telah menguasai topik Kristologi selama ia dapat mengatakan Yesus adalah Tuhan. Padahal Kristologi alkitabiah tidak hanya mencakup Ketuhanan Yesus saja. Anggapan ini menurunkan minat mahasiswa Kristen mengikuti PAK di perguruan tinggi.

\footnotetext{
${ }^{2}$ Jurgen Moltman. The Way Of Christ. (London: SCM Press, 1990), xiii

${ }^{3}$ Charles C. Ryrie. Buku 1: Teologi Dasar. (Yogyakarta: Yayasan Andi, 1991), 321.
}

Nadiem Makarim, selaku Mentri Pendidikan dan Kebudayaan Republik Indonesia, telah mengeluarkan kebijakan baru yaitu Kampus Merdeka. Kebijakan Kampus Merdeka berisi empat penyesuaian kebijakan terkait dengan perguruan tinggi. Kebijakkan ini diharapkan dapat meringankan beban perguruan tinggi terkait dengan urusan administrasi.

Kebijakkan keempat kampus merdeka mempersilahkan mahasiswa untuk memilih mata kuliah di luar program studinya. Dengan kebijakkan ini mahasiswa juga dapat mengganti beberapa mata kuliah dengan praktek, pengabdian, magang dan penelitian. ${ }^{4}$ Kebijakkan ini diharapkan mahasiswa dapat meningkatkan kompetensinya dengan keahlian di luar program studi yang dipelajari.

Kebijakkan Kampus Merdeka merupakan kebijakkan yang baik dan patut untuk diterapkan di perguruan tinggi. Akan tetapi tanpa pendampingan dan penyusunan kurikulum yang baik maka mahasiswa dapat menjadikan mata kuliah PAK sebagai salah satu pilihan saja. Kondisi mahasiswa di atas memungkinkan hal ini terjadi.

Peneliti beranggapan bahwa Kristologi alkitabiah adalah penting bagi mahasiswa sehingga PAK bukanlah suatu pilihan bagi mahasiswa. Oleh karena itu, peneliti hendak mengetahui pengaruh PAK dalam peningkatkan pemahaman mahasiswa Kristen tentang Kristologi alkitabiah. Tujuan dari penelitian ini adalah membuktikan bahwa PAK dapat meningkatkan pemahaman mahasiswa Kristen tentang Kristologi alkitabiah.

\footnotetext{
${ }^{4}$ Wisnubro. Empat Kebijakan Kampus Merdeka Belajar Ala Menteri Nadiem. https://jpp.go.id/humaniora/ pendidikan/340495empat-kebijakan-kampus-merdeka-belajar-alamenteri-nadiem. Diakses tanggal 5 Februari 2020 jam 13.36
} 


\section{RUMUSAN MASALAH}

Berdasarkan latar belakang di atas, maka permasalahan yang akan dimunculkan dalam penelitian ini adalah pertama, mahasiswa belum memiliki pemahaman yang sempurna tentang Kristologi alkitabiah. Kedua, belum diketahuinya pengaruh PAK terhadap pemahaman mahasiswa Kristen tentang Kristologi alkitabiah.

Masalah dalam penelitian ini diberikan batas yaitu pengaruh PAK terhadap pemahaman mahasiswa Kristen semester satu di Fakultas Ilmu Sosial dan Ilmu Politik Universitas Sebelas Maret Surakarta tentang Kristologi alkitabiah.

Masalah penelitian ini dirumuskan menjadi "Bagaimana pengaruh Pendidikan Agama Kristen terhadap pemahaman mahasiswa Kristen semester satu Fakultas Ilmu Sosial dan Ilmu Politik Universitas Sebelas Maret Surakarta tentang Kristologi alkitabiah?"

Penelitian ini bertujuan untuk mengetahui pengaruh Pendidikan Agama Kristen terhadap pemahaman mahasiswa Kristen semester satu Fakultas Ilmu Sosial dan Ilmu Politik Universitas Sebelas Maret Surakarta tentang Kristologi alkitabiah.

Penelitian ini memberikan manfaat teoritis untuk mengetahui pengaruh Pendidikan Agama Kristen terhadap pemahaman mahasiswa Kristen tentang Kristologi alkitabiah. Manfaat teoritis lain yaitu memberikan pengetahuan seberapa banyak Pendidikan Agama Kristen mempengaruhi pemahaman mahasiswa Kristen semester satu tentang Kristologi alkitabiah.

Penelitian ini bermanfaat secara praktis bagi mahasiswa yaitu dapat meningkatkan pemahaman tentang Yesus Kristus sehingga dapat meneladani-Nya dengan baik. Mahasiswa akan lebih bersemangat dalam perkuliahan Pendidikan Agama Kristen yang ditunjukkan dengan kesediaan mengikuti setiap aktifitas dalam pembelajaran.
Manfaat praktis bagi dosen yaitu dapat memanfaatkan Pendidikan Agama Kristen sebagai sarana memperkenalkan Kristus kepada mahasiswa. Dosen juga memperoleh masukan untuk meningkatkan semangat mahasiswa Kristen untuk menyatakan identitasnya sebagai pengikut Kristus di masyarakat.

Bagi perguruan tinggi, penelitian ini dapat menjadi masukkan untuk penyusunan kurikulum dalam penerapan program Kampus Mereka.

\section{Pendidikan Agama Kristen}

Kognitif atau pengetahuan bukanlah satu-satunya aspek yang ingin dididik oleh perguruan tinggi. Aspek yang lain yang tidak kalah penting adalah kepribadian dan sikap atau lebih dikenal dengan aspek afektif. Kerinduan perguruan tinggi dalam melatih kepribadian mahasiswa adalah dengan mengadakan mata kuliah Pendidikan Agama yang merupakan salah satu mata kuliah pengembangan kepribadian. ${ }^{5}$

Mata Kuliah Pendidikan Agama diberikan sesuai dengan agama masingmasing mahasiswa. Mahasiswa Kristen dalam konteks penelitian ini memperoleh Mata Kuliah Pendidikan Agama Kristen. Mata Kuliah ini merupakan Mata Kuliah Wajib Umum bila mengacu pada amanat Undang-Undang Nomor 12 Tahun 2012 Pasal 35 ayat $3 .{ }^{6}$

Pendidikan Agama Kristen di Universitas Sebelas Maret Surakarta diarahkan kepada tujuan mahasiswa dapat memahami karya Allah yang penuh kasih. Untuk mencapai tujuan ini metode yang

\footnotetext{
${ }^{5}$ T. Haryono, et al. Pendidikan Agama Kristen. (Surakarta: Lembaga Pengembangan dan Penjaminan Mutu Pendidikan (LPPMP) Universitas Sebelas Maret, 2016), 1.

${ }^{6}$ Paristiyanti Nurwardani, et al. Buku Ajar Mata Kuliah Wajib Umum : Pendidikan Agama Kristen. (Direktorat Jenderal Pembelajaran dan Kemahasiswaan, Kementerian Riset, Teknologi, dan Pendidikan Tinggi, Republik Indonesia, 2016), iv.
} 
digunakan adalah melalui persekutuan dengan Roh Kudus dan dengan saudara seiman lain serta dengan pembelajaran Alkitab yang kontekstual. Sehingga hasil akhir yang diperoleh adalah mahasiswa yang serupa Yesus dalam berbagai aspek kehidupan yang dibuktikan dengan tanggung jawab pribadi dan kepedulian terhadap sesama manusia. ${ }^{7}$

Pendidikan Agama Kristen memiliki peran untuk mentransmisikan kekristenan alkitabiah dari generasigenerasi. ${ }^{8}$ Pendidikan Agama Kristen membekali mahasiswa dengan nilai-nilai kekristenan yang terbagi menjadi 10 subkajian. Sepuluh subkajian itu adalah Tuhan Yang Maha Esa, manusia, Jemaat, moral, ilmu pengetahuan, teknologi dan seni, masyarakat, budaya, politik, hukum dan kerukunan umat beragama. ${ }^{9}$

Kristologi alkitabiah

Pengajaran mengenai Yesus Kristus umumnya dibagi menjadi dua, siapa Yesus (pribadi Yesus) dan karyaNya. Pelajaran tentang karya Yesus di dunia ini (terutama karya keselamatan) disebut soteriologi. Sedangkan pelajaran tentang siapa Kristus disebut Kristologi. ${ }^{10}$

Kristologi merupakan salah satu bagian dari dogmatika Kristen. Dogmatika merupakan hasil dari penelitian manusia terhadap Alkitab sebagai wahyu khusus dari Allah. Oleh karena itu sumber utama dalam kajian Kristologi adalah Alkitab. ${ }^{11}$

\footnotetext{
${ }^{7}$ T. Haryono. Hubungan Pendidikan Agama Kristen di Universitas Sebelas Maret dengan Pemahaman Soteriologi Mahasiswa. Jurnal Penelitian: Sekolah Tinggi Teologi Gamaliel Vol. 1 No. 2. (Surakarta: STT Gamaliel, 2013), 2.

${ }^{8}$ Daniel Nuhamara. Pembimbing PAK. (Bandung: Jurnal Info Media, 2009), 6.

9 T. Haryono, et al. Pendidikan Agama

Kristen. (Surakarta: Lembaga Pengembangan dan Penjaminan Mutu Pendidikan (LPPMP) Universitas Sebelas Maret, 2016), 2-3.

${ }^{10}$ Charles C. Ryrie. Teologi Dasar : Buku 1. (Yogyakarta: Yayasan Andi, 1991), 321.

${ }^{11}$ G.C. van Niftrik dan B.J. Boland. Dogmatika Masa Kini. (Jakarta: Gunung Mulia, 2015), 18-19.
}

Yesus Kristus merupakan salah satu pribadi Allah dalam Tirtunggal. Oleh karena itu, Yesus Kristus memiliki sifat keilahian. Berikut bukti-bukti keilahian Yesus. Pertama, Yesus memiliki nama atau penyebutan yang sama dengan Allah dalam Alkitab. Yesus sering disebut dengan Allah (Ibrani 1:8, Maz 45:6-7, Yohanes 20:28, Titus 2:13), Tuhan (Matius 22:44, Roma 10:9-13, Ibrani 1:10, Mazmur 102:25), dan Putra Allah (Yohanes 5:18, 25).

Kedua, Yesus memiliki atribut atau sifat yang seperti Allah. Yesus hidup untuk selama-lamanya atau kekal (Ibrani 1:8, Mikha 5:2). Ia sudah ada sebelum Abraham (Yohanes 8:58) dan berasal dari sorga (Yohanes 3:13). ${ }^{12}$ Yesus juga mahahadir (Matius 28:20), mahatahu (Yohanes 2:25), dan mahakuasa (Mat 28:18). Yesus juga tidak berubah seperti Allah (Ibrani 13:8, Maleakhi 3:6).

Ketiga, Yesus dapat melakukan perbuatan yang hanya dapat dilakukan oleh Allah. Yesus turut menciptakan dan memelihara dunia dan segala isinya (Yohanes 1:1-3, Kolose 1:17). Yesus mengampuni dosa manusia (Markus 2:112, Yesaya 43:25). Yesus melakukan mukjizat seperti menyembuhkan penyakit dan cacat tubuh.

Keempat, Yesus menerima sembah yang seharusnya diberikan kepada Allah. Dalam Yohanes 5:23, Yesus sendiri mengatakan bahwa Ia harus disembah seperti ketika menyembah Allah. Apabila Yesus bukan Allah maka hal itu adalah sesuatu yang sesat. ${ }^{13}$ Kesimpulan uraian di atas yaitu Yesus Kristus setara dengan Bapa dalam pribadi dan karya-Nya. Kesetaraan ini tidak dapat dikurangi atau dihilangkan.

\footnotetext{
${ }^{12}$ Paul Enns. The Moody Handbook of Theology, Revisied and Expanded (1). (Malang: Literatur Saat, 2019), 243-244.

${ }^{13}$ Paul Enns. The Moody Handbook of Theology, Revisied and Expanded (1). (Malang: Literatur Saat, 2019), 255-256.
} 
Arti penting keilahian Yesus terkait dengan karya penyelamatan manusia. Yesus dapat menjadi juru selamat seluruh dunia karena Dia adalah Allah. Bila Yesus bukan Allah maka Dia tidak dapat mengampuni dosa manusia. Pengampunan dosa hanya dilakukan oleh Allah saja (Matius 9:1-8, Markus 2:1-12, Lukas 5:17-26). ${ }^{14}$

Arti penting keilahian Yesus yang kedua adalah tentang dampak penebusanNya. Kurban penebusan di Perjanjian Lama menggunakan hewan (lembu, domba, burung) harus dilakukan berulangulang karena nilai hewan lebih rendah dari manusia. Apabila kurban penebusan itu adalah Allah yang jauh lebih bernilai dari manusia maka penebusan itu dapat berlaku untuk semua orang tanpa batasan waktu. Dengan Yesus adalah Allah maka nilai kematian-Nya tidak terbatas. ${ }^{15}$

Yesus dalam keallahan-Nya berinkarnasi untuk turun ke dunia manusia. Inkarnasi berarti "di dalam daging". Inkarnasi merujuk pada Yesus Kristus yang adalah Allah serta kekal menambahkan natur manusia dalam dirinya melalui kelahiran-Nya di bumi ${ }^{16}$. Inkarnasi Yesus ini melalui proses yaitu di kandung dalam Roh Kudus dan lahir melalui anak dara yaitu Maria.

Inkarnasi ini membuat Yesus menjadi manusia. Bukti Yesus menjadi manusia adalah Ia memiliki daging dan darah (tubuh fisik). Karena memiliki tubuh fisik ini Yesus dapat disentuh, merasakan lapar dan sakit seperti manusia pada umumnya. Tubuh fisik Yesus juga mengalami pertubuhan layaknya manusia.

${ }^{14}$ Chris Marantika. Yesus Itu Tuhan dalam Yesus Kristus Allah, Manusia Sejati. (Surabaya: PASTI dan YAKIN, 1983), 13.

${ }^{15}$ Paul Enns. The Moody Handbook of Theology, Revisied and Expanded (1). (Malang: Literatur Saat, 2019), 253.

${ }^{16}$ Paul Enns. The Moody Handbook of Theology, Revisied and Expanded (1). (Malang: Literatur Saat, 2019), 249.
Yesus mengalami fase bayi, anak-anak, dan dewasa.

Bukti kemanusiaan berikutnya adalah Yesus lahir dari rahim wanita sehingga Yesus memiliki keluarga, silsilah dan nama atau julukan. ${ }^{17}$ Dalam kitabkitab Injil Yesus menyebut dirinya Anak Manusia setidaknya 80 kali. Yesus juga memiliki silsilah dan keluarga yang dicatat di Injil Matius dan Lukas. Pada Lukas 2 juga dicatat Yesus memiliki keluarga yang taat terhadap Hukum Taurat.

Bukti lain adalah Yesus juga memiliki jiwa dan roh manusia. Yesus sebelum disalibkan merasa takut (yohanes 12:27). Ketika Yesus mengunjungi Maria saat Lazarus meninggal, Dia menangis (Yohanes 11:33). Hal ini memperlihatkan bahwa Yesus sama dengan manusia yang memiliki emosi karena memiliki jiwa dan $\operatorname{roh}^{18}$.

Yesus sebagai manusia tidak berdosa. Ketidakberdosaan Yesus Kristus berarti Ia tidak pernah melakukan perbuatan yang melanggar kehendak dan hukum Allah semasa di bumi. Bahkan didalam keterbatasannya sebagai manusia (lapar, haus, letih), Dia tidak pernah berdosa. Setiap fase hidupnya dari anakanak hingga dewasa, Yesus suci dan tanpa dosa. ${ }^{19}$

Bukti Yesus tidak berdosa terlihat dari kesaksian Alkitab. Alkitab menyaksikan bahwa Yesus adalah anak yang kudus (Lukas 1:35). Musuh-musuhNya tidak dapat membuktikan Yesus melakukan kesalahan (Yoh 8:46). Bahkan ketika masa penghakiman hingga penyaliban, Ia diakui tidak bersalah (Matius 27:4, Lukas 27:24; Lukas 23:14, 22; Yohanes 18:38; Lukas 23:15). Penulis

\footnotetext{
${ }^{17}$ Ichwei G. Indra. Teologi Sistematis. (Bandung: Lembaga Literatur Baptis, 2010), 137

${ }^{18}$ Paul Enns. The Moody Handbook of

Theology, Revisied and Expanded (1). (Malang: Literatur Saat, 2019), 252.

${ }^{19}$ Charles C. Ryrie. Teologi Dasar : Buku 1. (Yogyakarta: Yayasan Andi, 1991), 357.
} 
kitab perjanjian Baru juga menyaksikan bahwa Yesus tanpa dosa (2 Korintus 5:21, 1 Petrus 2:22, 1 Yohanes 3:5, Ibrani $4: 15){ }^{20}$

Yesus mengalami pencobaan seperti halnya manusia. Namun perbedaannya adalah Yesus tidak berdosa atau tetap melakukan yang benar dalam pencobaan itu. Oleh karena itu, Yesus juga dapat bersimpati dan memberi teladan kepada manusia.

\section{METODE PENELITIAN}

Penelitian ini menggunakan pendekatan kuantitatif dengan jenis penelitian quasi experiment dan metode evaluasi one group pretest postest. Quasi Eksperimen adalah suatu metode penelitian eksperimen yang penempatan unit terkecil eksperimen ke dalam kelompok eksperimen dan kontrol tidak dilakukan dengan acak (nonrandom assignment). ${ }^{21}$ Populasi yaitu mahasiswa Kristen angkatan 2019 yang mengambil Mata Kuliah Pendidikan Agama Kristen di Fakultas Ilmu Sosial dan Ilmu Politik Universitas Sebelas Maret Surakarta (UNS) sebanyak 30 mahasiswa. Besarnya sampel sama dengan jumlah populasi. Instrumen penelitian yaitu Angket Kuesioner. Sample validasi sebanyak 25 mahasiswa Kristen angkatan 2019 dari Fakultas yang berbeda dengan populasi penelitian. Dilakukan Validitas dan Reliabilitas instrumen. Teknik analisis data yaitu Uji Hipotesis Paired Sampel T test. Uji normalitas dan Uji Homogenitas. Uji sumbangan efektivitas Unvariate R Square. Variabel X $=$ Pembelajaran Agama Kristen dan Variabel $Y=$ Pemahaman tentang Kristologi alkitabiah. Hipotesis penelitian ini adalah PAK berpengaruh efektif

\footnotetext{
${ }^{20}$ Charles C. Ryrie. Teologi Dasar : Buku 1. (Yogyakarta: Yayasan Andi, 1991), 358.

${ }^{21}$ T. Dicky Hastjarjo. Rancangan Eksperimen-Kuasi. Buletin Psikologi 2019, Vol. 27, No. 2. https://jurnal.ugm.ac.id/buletinpsikologi. 189
}

terhadap pemahaman mahasiswa Kristen di perguruan tinggi tentang Kristologi alkitabiah.

\section{HASIL DAN PEMBAHASAN}

\section{Uji normalitas.}

Uji normalitas data dengan sampel $<200$ menggunakan rumus kolmogorov smirnov. Dasar pengambilan keputusan jika nilai sig $\geq 0,05$ maka data berdistribudi normal, sedangkan jika nilai sig $\leq 0,05$ maka data tidak berdistribusi normal. Berdasar hasil uji normalitas yang dilakukan pada keselurahan data diketahui bahwa seluruh data memiliki nilai signifikansi $0,11 \geq 0,05$ sehingga dapat disimpulkan seluruh data, berdistribusi normal. Dengan data yang terdistribusi secara normal maka data-data ini dapat mewakili kondisi dari populasi dan dapat dilakukan pengujian dengan menggunakan statisik parametrik.

\section{Uji homogenitas}

Uji homogenitas dalam penelitian ini menggunakan model Levene Test for Equality of Variance. Dasar dari pengambilan keputusan ini adalah, jika nilai signifikansi $\geq 0,05$ maka varian dinyatakan memiliki sifat yang sama atau homogen. Berdasarkan uji homogenitas yang dilakukan di ketahui, data pretest menunjukkan nilai signifikansi $0,527 \geq$ 0,05. Sedangkan data posttest menunjukkan nilai signifikansi $0,228 \geq$ 0,05. Terlihat bahwa seluruh data memeliki nilai signifikansi $\geq 0,05$ sehingga disimpulkan seluruh data bersifat homogen.

Uji hipotesis

Uji hipotesis dalam penelitian ini dilakukan dengan menggunakan paired sample T-test karena hanya menggunakan satu kelompok penelitian saja dengan menguji nilai pretest dan posttest. Dengan dasar pengambilan keputusan apabila nilai signifikansi $\leq 0,05$ maka terdapat 
perbedaan yang signifikan antara pretest dan posttest. Berikut ini merupakan hasil dari uji hipotesis.

\section{Paired Samples Test}

\begin{tabular}{|c|c|c|c|c|c|c|c|c|}
\hline & \multicolumn{5}{|c|}{ Paired Differences } & \multirow[b]{3}{*}{$\mathrm{t}$} & \multirow[b]{3}{*}{$\mathrm{df}$} & \multirow{3}{*}{$\begin{array}{l}\text { Sig. } \quad(2- \\
\text { tailed })\end{array}$} \\
\hline & \multirow[b]{2}{*}{ Mean } & \multirow{2}{*}{$\begin{array}{l}\text { Std. } \\
\text { Deviation }\end{array}$} & \multirow{2}{*}{$\begin{array}{l}\text { Std. } \\
\text { Error } \\
\text { Mean }\end{array}$} & \multicolumn{2}{|c|}{\begin{tabular}{|llr}
$95 \%$ & Confidence \\
Interval of the \\
Difference
\end{tabular}} & & & \\
\hline & & & & Lower & Upper & & & \\
\hline $\begin{array}{ll}\text { Pair } & \text { PRETEST } \\
1 & \text { POSTTEST }\end{array}$ & 1.700 & 2.020 & .369 & -2.454 & -.946 & 4.610 & 29 & .000 \\
\hline
\end{tabular}

Tabel 1. Tabel paired test

Diketahui nilai sig (2-tailed) menunjukkan nilai $0,000 \leq 0,05$ artinya ada pengaruh yang signifikan antara pretest dan posttest. sehingga dapat diartikan juga bahwa ada pengaruh yang signifikan pendidikan agama kristen terhadap pemahaman tentang kristologi. Berikut data lengkap nilai pretest dan posttest.

\section{Uji sumbangan efektifitas}

Uji sumbangan efektifitas dalam penelitian ini menggunakan uji regresi. Berdasarkan hasil uji regresi menunjukkan nilai R Square sebanyak 47,9\%. Hal ini menunjukkan bahwa pendidikan agama Kristen memberikan sumbangan efektif terhadap pemahaman tentang Kristologi alkitabiah sebanyak 47,9\%.

\section{Pembahasan}

Hasil dari uji hipotesis dan uji sumbangan efektifitas memperlihatkan bahwa hipotesis peneliti terbukti. Oleh karena itu dapat diketahui bahwa Pendidikan Agama Kristen berpengaruh terhadap pengetahuan mahasiswa tentang Kristologi alkitabiah. Pengaruh Pendidikan Agama Kristen adalah menaikkan pengetahuan mahasiswa tentang Kristologi alkitabiah sebesar 47, 9\%.

Hasil signifikan ini ditopang oleh metode pembelajaran yang digunakan peneliti di kelas. Peneliti memanfaatkan kegiatan dalam kelas dan di luar kelas untuk menyampaikan materi Kristologi alkitabiah. Peneliti menggunakan metode pembelajaran Alkitab hermeneutis holistic kontekstual $^{22}$, diskusi, presentasi, ceramah, dan tugas pribadi untuk menyampaikan materi di dalam kelas. Sedangkan di luar kelas peneliti menggunakan kegiatan persekutuan mahasiswa, kelompok pemuridan KTBK (Kelompok Tumbuh Bersama Kontekstual), retreat mahasiswa baru dan Pembekalan Rohani Awal Tahun Akademik yang bekerja sama dengan Persekutuan Mahasiswa Kristen Fakultas Ilmu Sosial dan Ilmu Politik Universitas Sebelas Maret. Dengan berbagai metode ini mahasiswa dapat lebih mudah mengerti materi Kristologi alkitabiah.

Intensitas mengajar dengan materi Kristologi alkitabiah juga berperan dalam memberi signifikasi ini. Mahasiswa menerima empat kali pembelajaran Kristologi alkitabiah di dalam kelas dan empat kali di luar kelas. Oleh karena itu mahasiswa dalam penelitian ini

${ }^{22}$ Daniel Fajar Panuntun dan Eunike Paramita. Hubungan Pembelajaran Alkitab terhadap Nilai-Nilai Hidup Berbangsa dalam Pemuridan Kontekstual (Kelompok Tumbuh Bersama Kontekstual). Jurnal Gamaliel: Teologi Praktika Vol 1, No 2, September 2019. http://jurnal.sttgamaliel.ac.id/index.php/gamaliel/article/view/30/1 4, 108 . 
memperoleh minimal delapan kali penyampaian materi Kristologi alkitabiah.

\section{KESIMPULAN DAN SARAN}

Berdasarkan pembahasan di atas, maka kesimpulan dari penelitian ini adalah Pendidikan Agama Kristen berpengaruh meningkatkan pemahaman mahasiswa tentang Kristologi alkitabiah sebesar $47,9 \%$.

Dari kesimpulan di atas, peneliti memberikan saran yaitu pertama, kepada

\section{DAFTAR PUSTAKA}

Charles C. Ryrie. Teologi Dasar : Buku 1. (Yogyakarta: Yayasan Andi, 1991)

Chris Marantika. Yesus Itu Tuhan dalam Yesus Kristus Allah, Manusia Sejati. (Surabaya: PASTI dan YAKIN, 1983)

Daniel Fajar Panuntun dan Eunike Paramita. "Hubungan Pembelajaran Alkitab terhadap Nilai-Nilai Hidup Berbangsa dalam Pemuridan Kontekstual (Kelompok Tumbuh Bersama Kontekstual)". Jurnal Gamaliel : Teologi Praktika Vol 1, No 2. (2019). http://jurnal.sttgamaliel.ac.id/index.php/gamaliel/ article/view/30/14.

Daniel Nuhamara. Pembimbing PAK. (Bandung: Jurnal Info Media, 2009)

Dasim Budimansyah. Tantangan Globalisasi Terhadap Pembinaan Wawasan Kebangsaan Dan Cinta Tanah Air Di Sekolah. Jurnal Penelitian Pendidikan Vol. 11, No. 1, April 2010.

G.C. van Niftrik dan B.J. Boland. Dogmatika Masa Kini. (Jakarta: Gunung Mulia, 2015) dosen agar lebih kreatif dalam mengajar dan lebih sering mengulangi materi Kristologi alkitabiah. Kedua, kepada perguruan tinggi dan tim penyusun kurikulum agar terus mendampingi mahasiswa sehingga ketika kebijakkan kampus merdeka diterapkan, mahasiswa tetap akan mengikuti Mata Kuliah Pendidikan Agama Kristen. Ketiga, diperlukan penelitian lebih lanjut untuk mengetahui efektifitas masing-masing metode pengajaran.

Ichwei G. Indra. Teologi Sistematis.

(Bandung: Lembaga Literatur Baptis, 2010)

Jurgen Moltman. The Way Of Christ. (London: SCM Press, 1990)

Paristiyanti Nurwardani, et al. Buku Ajar Mata Kuliah Wajib Umum : Pendidikan Agama Kristen. (Direktorat Jenderal Pembelajaran dan Kemahasiswaan, Kementerian Riset, Teknologi, dan Pendidikan Tinggi, Republik Indonesia, 2016)

Paul Enns. The Moody Handbook of Theology, Revisied and Expanded (1). (Malang: Literatur Saat, 2019)

T. Dicky Hastjarjo. Rancangan Eksperimen-Kuasi. Buletin Psikologi 2019, Vol. 27, No. 2. https://jurnal.ugm.ac.id/buletinpsi kologi.

Timotius Haryono, et al. Pendidikan Agama Kristen. (Surakarta: Lembaga Pengembangan dan Penjaminan Mutu Pendidikan (LPPMP) Universitas Sebelas Maret, 2016) Hubungan Pendidikan Agama Kristen di Universitas Sebelas Maret dengan Pemahaman Soteriologi Mahasiswa. Jurnal Penelitian: Sekolah Tinggi Teologi Gamaliel Vol. 1 No. 2. (Surakarta: STT Gamaliel, 2013) 
Jurnal Gamaliel : Teologi Praktika

Vol 2, No 1, Maret 2020

Wisnubro. Empat Kebijakan Kampus

Merdeka Belajar Ala Menteri

Nadiem.

https://jpp.go.id/humaniora/

pendidikan/340495-empat-

kebijakan-kampus-merdeka-

belajar-ala-menteri-nadiem.

Diakses tanggal 5 Februari 2020

jam 13.36. 